\title{
PEMANFAATAN MEDIA SOFTWARE TRACKER UNTUK MENINGKATKAN KEMAMPUAN BERPIKIR KRITIS PESERTA DIDIK PADA MATERI IMPULS DAN MOMENTUM DI SMKN 1 SOREANG
}

\author{
Furi Chorina Agustin1, Yudi Dirgantara' ${ }^{1}$ Ade Yeti Nuryantini ${ }^{1}$
}

\author{
${ }^{1}$ Program Studi Pendidikan Fisika, Fakultas Tarbiyah dan Keguruan, UIN Sunan Gunung Djari \\ Bandung, Indonesia \\ E-mail: chorina15@gmail.com
}

\begin{abstract}
ABSTRAK
Penelitian ini berawal dari kurangnya pemanfaatan media pembelajaran saat proses pembelajaran. Metode pembelajaran yang digunakan oleh guru kurang bervariasi sehingga peserta didik hanya dilatih pada kemampuan kognitif saja sedangkan untuk kemampuan berpikir tingkat tinggi seperti kemampuan berpikir kritis masih rendah. Salah satu alternatif yang dapat dilakukan untuk meningkatkan keterampilan berpikir kritis adalah dengan memanfaatkan media Software Tracker. Penelitian ini bertujuan untuk mengetahui peningkatan keterampilan berpikir kritis peserta didik melalui pemanfaatan media Software Tracker pada materi impuls dan momentum. Metode penelitian yang digunakan adalah Pre-Eksperiment dengan design One-Group PretestPosttest Design. Sampel penelitian ini menggunakan teknik Purposive Sampling. Instrumen penelitian yang digunakan dalam penelitian ini adalah tes keterampilan berpikir kritis peserta didik materi impuls dan momentum untuk mengukur kemampuan berpikir kritis peserta didik. Teknik analisis data menggunakan uji normalitas, dan uji t terhadap nilai n-gain yang dinormalisasi dari nilai pretest dan postest peserta didik menggunakan Microsoft Excel. Hasil penelitian menunjukkan bahwa kemampuan berpikir kritis peserta didik meningkat setelah memanfaatkan media Software Tracker saat pembelajaran. Hasil penelitian ini dibuktikan dari nilai signifikan uji ttabel sebesar 1,691 sedangkan thitung sebesar 24,53 yang berarti H0 ditolak dan Ha diterima. Hasil penelitian ini menunjukkan bahwa pemanfaatan media Software Tracker pada materi impuls dan momentum memiliki dampak yang positif terhadap peningkatan kemampuan berpikir kritis peserta didik.
\end{abstract}

Kata kunci: keterampilan berpikir kritis, Software Tracker, impuls dan momentum.

\begin{abstract}
This study originated from the lack of utilization of learning media during the learning process. Teaching methods used by teachers are less varied so that learners are only trained in cognitive abilities only while for high-level thinking skills such as critical thinking ability is still low. One alternative that can be done to improve the skills of critical thinking is to utilize the Software Tracker media. This study aims to determine the improvement of critical thinking skills of learners through the use of Software Tracker media on the material impulse and momentum. The research method used is Pre-Experiment with design One-Group Pretest-Posttest Design. The sample of this research using Purposive Sampling technique. The research instrument used in this research is the critical thinking skills of the students of impulse material and momentum to measure the critical thinking ability of learners. The data analysis technique uses normality test, and t test to normalized n-gain value from pretest and posttest value of learners using Microsoft Excel. The results showed that the critical thinking skills of learners increased after utilizing the Software Tracker media during learning. The result of this research is proved from the significant value of ttable test of 1.691 while $t$ count is 24.53 which means $\mathrm{HO}$ is rejected and Ha accepted. The results of this study indicate that the use of Software Tracker media on the material impulse and momentum have a positive impact on improving the critical thinking skills of learners.
\end{abstract}

Keywords: critical thinking skills, Software Tracker, impulse and momentum.

DOI: http://dx.doi.org/10.15575/jtlp.v2i1.6583

Received: 3 Agustus 2016 ; Accepted: 18 Januari 2017; Published: 1 Maret 2017 


\section{PENDAHULUAN}

Saat ini kita berada pada abad 21 yang ditandai dengan perkembangan teknologi yang pesat, sehingga sains dan teknologi merupakan salah satu landasan penting dalam pembangunan bangsa. Pembelajaran sains diharapkan dapat menghantarkan peserta didik memenuhi kemampuan abad 21, kemampuan yang diperlukan pada abad 21, yaitu: 1) keterampilan belajar dan berinovasi yang meliputi berpikir kritis dan mampu menyelesaikan masalah, kreatif dan inovatif, serta mampu berkomunikasi dan berkolaborasi; 2) terampil untuk menggunakan media, teknologi, informasi dan komunikasi (TIK); 3) kemampuan untuk menjalani kehidupan dan karir, meliputi kemampuan beradaptasi, luwes, berinisiatif, mampu mengembangkan diri, memiliki kemampuan sosial dan budaya, produktif, dapat dipercaya, memiliki jiwa kepemimpinan, dan tanggung jawab (Kementrian Pendidikan \& Kebudayaan, 2016 : 5).

Kecanggihan dunia teknologi memberi banyak kesempatan untuk guru lebih kreatif dalam mengembangkan pembelajaran di kelas terutama untuk mata pelajaran fisika. Mata pelajaran fisika selalu dipandang sebagai mata pelajaran yang sulit, namun dengan adanya perkembangan teknologi guru akan lebih bisa meminimalisasikan mata pelajaran yang dianggap sulit menjadi lebih menarik. Misalnya saat pembelajaran berlangsung menampilkan video, memanfaatkan media PHET, dan Software Tracker. Pada kenyataannya berdasarkan hasil studi pendahuluan pemanfaatan TIK belum sepenuhnya dilakukan oleh guru sehingga proses pembelajaran kurang bervariasi peserta didik hanya dilatih pada kemampuan kognitifnya saja sedangkan untuk kemampuan berpikir kritis eserta didik masih rendah.

Media pembelajaran yang diharapkan dapat menciptakan kondisi pembelajaran untuk meningkatkan keterampilan berpikir kritis serta memungkinkan peserta didik dapat belajar secara aktif dan menyenangkan. Salah satu media pembelajaran yang memungkinkan adalah penggunaan Software Tracker saat pembelajaran fisika. Software Tracker merupakan perangkat lunak yang mampu menganalisis video digital. Dari file video yang direkam oleh kamera gerak suatu benda dapat dianalisis (Hantoro, 2014 : 6).

Dengan adanya Software Tracker guru dan peserta didik akan sama-sama merasakan kecanggihan dan manfaat teknologi yang sudah berkembang dengan pesat. Pembelajaran akan lebih menarik perhatian karena ini merupakan hal baru bagi peserta didik. Namun Software Tracker masih mempunyai kekurangan yaitu tidak dapat digunakan pasa seluruh materi fisika. Adapun materi yang digunakan dalam penelitian ini adalah impuls dan momentum.

Analisis melalui video dimungkinkan oleh karena teknologi komputer yang mampu menangkap dan menjalankan kembali gambar yang beresolusi tinggi dengan cukup mudah. Merekam video yang berupa aplikasi fisika dalam kehidupan sehari-hari adalah cara paling praktis untuk menampilkan kecepatan benda yang sesungguhnya (Tracker, et al, 2014: 5). Berdasarkan hasil penelitian (Habibbullah \& Sooko, 2014: 5) setelah menggunakan media Software Tracker saat pembelajaran peserta didik mengalami kenaikan baik berupa kualitas maupun kuantitas berupa komunikasi, mengamati, mengukur, dan interpretasi data.

Berdasarkan hasil penelitian dan analisis hubungan kecepatan terminal dan viskostas dengan video analisis Software Tracker, penggunaan video analisis Tracker dapat membantu menjelaskan peristiwa benda jatuh di dalam zat cair, mempermudah saat menganalisis pergerakan benda setiap detiknya (Budianto, 2014: 37). Analisis melalui video dimungkinkan oleh karena teknologi komputer mampu menangkap dan mengulang kembali gambar bergerak resolusi tinggi dengan cukup mudah. Peserta didik dapat mengkonsentrasikan pada gambaran gejala fisika dalam video dan bukan pada teknik pengumpulan data. Merekam video dari animasi opembelajaran fisika adalah cara paling praktis untuk menampilkan gerak suatu objek 
pengamatan yang sesungguhnya (Purwanti, 2014: 24).

Berdasarkan uraian di atas maka penelitian ini perlu dilakukan untuk pemanfaatan Software Tracker untuk melihat peningkatan keterampilan berpikir kritis pada materi impuls dan momentum

\section{METODE PENELITIAN}

Metode penelitian yang digunakan adalah PreEksperimen. Desain yang digunakan dalam penelitian ini adalah one-group pretest-posttest design. Penelitian ini dilakukan di SMKN 1 Soreang kelas X jurusan Teknik Elektronika Industri tahun ajaran 2016/2017. Sampel dalam penelitian ini adalah kelas X Teknik Elektronika Industri. Penentuan jumlah sample penelitian menggunakan teknik pengambilan sample Purposive Sampling.

Instrumen yang digunakan untuk mengukur keterlaksanaan pembelajaran dengan lembar observasi yang berisi 17 aktivitas guru dan peserta didik. Selain lembar observasi untuk mengukur keterlaksanaan pembelajaran peneliti menggunakan Lembar Kerja Peserta Didik (LKPD)

\section{HASIL DAN PEMBAHASAN}

Keterlaksanaan pembelajaran dapat ditinjau dari aktivitas guru dan peserta didik. Adapun hasilnya dapat dilihat pada tabel di bawah ini:

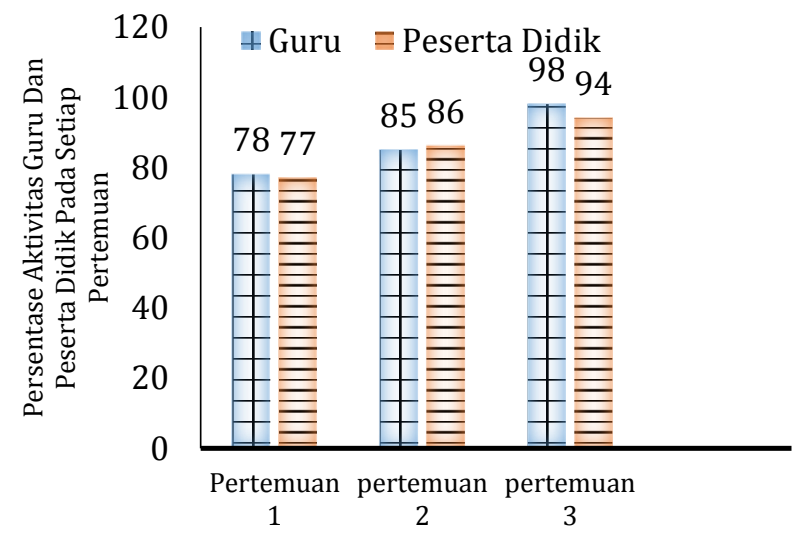

Gambar 1. Persentase Aktivitas Guru dan Peserta Didik pada Setiap Pertemuan
Berdasarkan Gambar 3.11 dapat diketahui bahwa pelaksanaan kegiatan pembelajaran dengan menggunakan media Software Tracker pada setiap pertemuan mengalami peningkatan. Pada pertemuan pertama rata-rata aktivitas guru sebesar 92\% dan aktivitas peserta didik 90\% dengan kategori baik. Kemudian pada pertemuan kedua rata-rata aktivitas guru sebesar 93\% dan aktivitas peserta didik sebesar 91\% dengan kategori baik. Selanjutnya pada pertemuan ketiga rata-rata aktivitas guru sebesar $94 \%$ dan aktivitas peserta didik sebesar 93\% dengan kategori sangat baik.

Selain dari aktivitas guru dan peserta didik, keterlaksanaan pembelajaran juga dapat ditinjau dari LKPD berikut hasil dari setiap pertemuan dengan menggunakan LKPD:

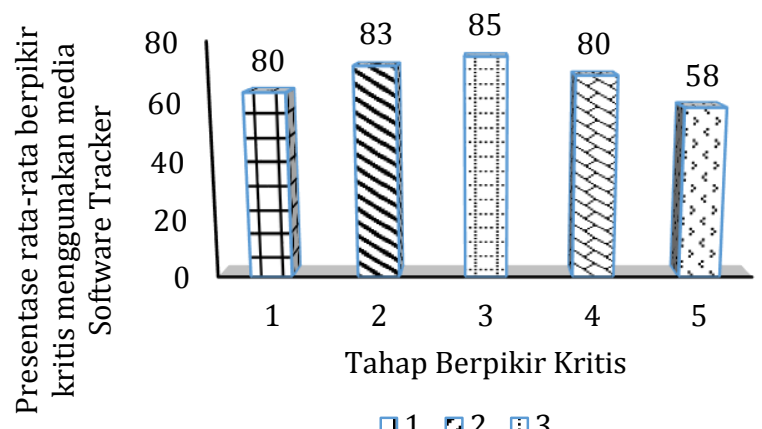

Gambar 3.10 Presentase Rata-rata LKPD Menggunakan Software Tracker Keterangan.

1. Memberikan penjelasan sederhana (Elementary Clarification)

2. Membangun keterampilan dasar (Bassic Support)

3. Membuat penjelasan lebih lanjut (Advanced Clarification)

4. Menyimpulkan (Infarance)

5. Strategi dan taktik (Strategies and Tactics)

Peningkatan berpikir kritis juga didukung oleh hasil ujinormalitas yang dapat dilihat pada tabel berikut: 
Tabel 1. Hasil Uji Normalitas Pretest dan Posttest

\begin{tabular}{ccc}
\hline Keterangan & Pretest & Posttest \\
\hline$(\mathrm{N})$ & 29 & 29 \\
$(\mathrm{dk})$ & 5 & 5 \\
$X^{2}$ hitung & 6 & 3 \\
$X_{\text {tabel }}^{2}$ & 11,01 & 11,01 \\
Hasil & $x_{\text {hitung }}^{2}<x_{\text {tabel }}^{2}$ & $x_{\text {hitung }}^{2}<x_{\text {tabel }}^{2}$ \\
& $\begin{array}{c}\text { Data terdistribusi } \\
\text { normal }\end{array}$ & $\begin{array}{c}\text { Data } \\
\text { terdistribusi } \\
\text { Keterangan }\end{array}$ \\
& & normal \\
\hline
\end{tabular}

Berdasarkan hasil uji normalitas tersebut didapatkan bahwa hasil pretest dan posttest keduanya menunjukkan bahwa data terdistribusi normal. Selanjutnya dilakukan uji hipotesis yang dilakukan dengan menggunakan uji parametrik (uji t) dengan taraf kepercayaan 5\% dapat dilihat pada Tabel berikut:

Tabel 2. Hasil Uji Hipotesis

\begin{tabular}{cc}
\hline Keterangan & Nilai \\
\hline thitung & 24,53 \\
ttabel & 1,691 \\
$\mathrm{db}$ & 28 \\
Hasil & thitung $>$ ttabel \\
Keterangan & terdapat peningkatan \\
& secara signifikan \\
\hline
\end{tabular}

Berdasarkan hasil uji $\mathrm{t}$ yang tercantum pada Tabel 3.20. diatas, nilai $t_{\text {hitung }}=24,53$. Adapun besar $t_{\text {tabel }}=1,691$ pada taraf signifikan 0,05. Hal tersebut menunjukan bahwa nilai $t_{\text {hitung }}>t_{\text {tabel }}$, sehingga diperoleh bahwa $H_{0}$ ditolak dan $H_{a}$ diterima.

Dengan demikian hasil pengujian hipotesis tersebut memberikan kesimpulan bahwa terdapat peningkatan keterampilan berpikir kritis peserta didik SMKN 1 Soreang setelah memanfaatkan media pembelajaran Software Tracker.

\section{KESIMPULAN}

Berdasarkan hasil pengolahan dan analisis data tentang pemanfaatan media Software Tracker untuk meningkatkan keterampilan berpikir kritis peserta didik pada materi impuls dan momentum diperoleh kesimpulan sebagai berikut:

1. Keterlaksanaan pembelajaran dengan memanfaatkan media Software Tracker termasuk kedalam kategori sangat baik, keterlaksanaan pembelajaran setiap pertemuannya mengalami peningkatan dengan kategori baik.

Terdapat peningkatan berpikir kritis peserta didik setelah dilakukan pembelajaran dengan menggunakan media Software Tracker. Hal ini dapat dilihat dari angka hasil perhitungan data menggunakan uji $t$ memperlihatkan bahwa Hipotesis Nol $\left(H_{0}\right)$ ditolak dan Hipotesis Alternatif $\left(H_{a}\right)$ diterima. Artinya terdapat peningkatan pemahaman konsep peserta didik setelah mengikuti pembelajaran dengan menggunakan media pembelajaran Software Tracker. Peningkatan ini juga dapat dilihat dari hasil pengolahan data pretest dan posttest serta $N$ - Gain. Nilai $N$ - Gain yang diperoleh dari data pretest dan posttest dengan kategori atau interpretasi sedang.

\section{UCAPAN TERIMAKASIH}

Peneliti bertimakasih kepada Bapak Drs. Yudi Dirgantara, M.Pd. selaku pembimbing I dan Ibu Dr. Hj. Ade Yeti Nuryantini, M.M.Pd, M.Si. selaku pembimbing II yang telah memberikan ilmu, motivasi serta arahannya sehingga tulisan ini dapat terselesaikan. Penulis juga berterima kasih kepada Bapak Ayi Rohmat Sumirat, S.Pd selaku kepala sekolah SMKN 1 Soreang. Drs. Supardan selaku guru fisika yang telah memberi izin dan kesempatan melaksanakan penelitian. 


\section{DAFTAR PUSTAKA}

Abdullah, Mikrajuddin. (2016). Fisika Dasar I. Institut teknologi Bandung

Ahmad ibn Abd al-Rahman al-Samiraa'I. (2011). Pengembangan Media Interaktif Elektronika di SMK. 5(1)

Zainal Arifin, (2012). Evaluasi Pembelajaran. Cetakan Ke-2 Edisi Revisi

Arikunto, Suharsimi. (2006). Prosedur Penelitian Suatu Pendekatan Praktek. Yogyakarta: Rineka Cipta

Arikunto, Suharsimi (2007). Dasar-dasar Evaluasi Pendidikan (Edisi Revisi). Jakarta: Bina Aksara

Arikunto, Suharsimi (2012). Dasar-dasar Evaluasi Pendidikan. Yogyakarta: Rineka Cipta

Arsyad, Azhar. 2016. Media Pembelajaran. Jakarta: PT Grafido Persada.

Danim, N. (2012). Media Pendidikan. Jakarta: Pustekkom Diknas \& PT. Raja Grafindo Perkasa.

Ely, M. (2012). Pengembangan Media Pembelajaran Berbasis Multimedia. Laporan Penelitian Dosen

Ennis, R. H. (2007). The Nature of Critical Thinking : An Outline of Critical Thinking Dispositions, 1-8.

Giancoli, Douglas C.(2001). Fisika. Edisi kelima Jilid 1. Jakarta: Penerbit Erlangga

Hantoro, B. B. (2014). Menyelidiki Hubungan Kecepatan Terminal Dan

Hantoro, B. B. (2014). Viskositas Zat Cair Dengan Video Analisis Tracker, (April), 35-37.

Hamalik, Oemar. (1994) Media Pendidikan. (Cetakan ke-7). Bandung: Penerbit: PT Citra Aditya Bakti.

Harliawan, H. danTripalupi. (2014). Penggunaan Media Pembelajaran Berbasis Tik Untuk Meningkatkan Hasil Belajar Ips Kelas Viii J Smp Negeri 5.

Hake, Richard. (1999). Analizing change/Gain Scores. American Educational Research Association's Division D, Measurement and Research Methodology Journal.
Hassoubah, Zaleha Izhab. (2007). Mengasah Pikiran Kreatif dan Kritis. Bandung: Nuansa

Hockicko, P. (2009). Video Analysis Of Motions Software Tracker.

Jong, Specht, M., dan Koper, R. (2008). Contextualised Media for Learning Contextualised Media for Learning, 11, 4153.

Karim, Normaya. (2015). Kemampuan Berpikir Kritis Siswa Dalam Pembelajaran Matematika Dengan Menggunakan Model Jucama Di Sekolah Menengah Pertama, 3(April).

Kemendikbud. (2016). Silabus Kurikulum 2013 untuk SMA/MA. Jakarta: Kemendikbud.

Leow, M. F. (2014). Interactive Multimedia Learning: Innovating Classroom Education In A Malaysian University, 13(2), 99-110.

Mahnun, O. N. (2012). MEDIA PEMBELAJARAN ( Kajian terhadap Langkah- langkah Pemilihan Media dan Implementasinya dalam Pembelajaran ), 37(1).

Muhammad Habibb Ulloh dan Sooko. (2014).Peningkatan Berpikir Kritis Siswa Setelah Menggunakan Software Tracker, 4(1), 15-22.

Noordyana, M. A. (2016). Meningkatkan Kemampuan Berpikir Kritis Matematis Siswa melalui Pendekatan Metacognitive Instruction, 8(April).

Paul, dkk. (2002). Kemampuan Berpikir Tingkat Tinggi Fisika Siswa. Interplus: Bekasi

Physics, O. S. (2009). This Paper Deals With Increasing The Key Competencies In Engineering By Analysing Real Life Situation Videos (Physical Problems) By Means Of Video Analysis And The Modelling 73, 73-80.

Rubric, M. (2007). Critical Thinking Competency Standards.

Saehana, S. (2013). Pengembangan Media Pembelajaran Interaktif Berbasis Komputer Untuk Siswa Smp Kelas VIII, 69-77.

Sugiyono. (2007). Metode Penelitian Kuantitatif Kualitatif dan R\&D. Bandung: Alfabeta 
Supardi, P. (2012). Media Teknologi di Sekolah. 4(1).

Tawil, dkk. (2013). Making Thinking Visible. National Science Teacher Assosiation

Tracker, A., Purwanti, S., dan Pramudya, Y. (2014). Penentuan Koefisien

Restitusi Tumbukan 2 Bola dengan Video, (April), 27-30.

Utami, (2013). Penelitian Tindakan Kelas Pembelajaran Fisika

Wibowo, dkk. (2012). Pentingnya Berpikir Kritis Peserta Didik pada Pembelajaran Fisika. 4(1).

Yuliana Bahri, (1998). Guru dan Anak Didik dalam Interaksi Edukatif. Jakarta: PT Rineka Cipta

Yusuf Hadi, Miarso. (2007). Media Kontekstual, $5(1)$ 